\title{
TOXOPLASMA GONDII: ITS EFFECT ON THE OVINE POPLITEAL LYMPH NODE
}

\author{
D. Buxton, H. R. P. Miller, J. Finlayson and G. R. Wallace \\ Moredun Research Institute, 408 Gilmerton Road, Edinburgh EH17 7JH \\ Plates XXIX-XXXI
}

\begin{abstract}
SUMmaRY. Four non-immune sheep and two with naturally acquired antibody were inoculated subcutaneously in the lower part of the leg with 100 cysts of Toxoplasma gondii. Two other non-immune sheep were given a control inoculum. Efferent lymph from the popliteal nodes on the side of the injection was collected via a cannula and injected into mice. Live toxoplasms were present in the lymph of non-immune sheep from day 2 until day 15, at which time the experiment was terminated. Corresponding samples of lymph from the one immune animal tested were almost always negative.

Severe pathological changes were present in lymph nodes from non-immune sheep. Gross enlargement, loss of architecture, haemorrhages, and some necrosis occurred, and the sinuses were packed with plasma cells and plasmablasts. Changes in the nodes of immune sheep were similar but less striking, with retention of architecture, no haemorrhages and no necrosis. It was concluded that the lymphadenopathy in sheep is similar to that in rabbits, mice and man with toxoplasmosis.
\end{abstract}

\section{INTRODUCTION}

Toxoplasma gondii has a worldwide distribution and infects most species of warm-blooded animals (Frenkel, 1973). In sheep it causes abortion and neonatal mortality (Hartley and Marshall, 1957; Beverley and Watson, 1961, 1971; Hartley and Moyle, 1968) whereas in man the commonest clinical manifestation is lymphadenopathy (Beverley, 1974).

Relatively little is known of the effects of $T$. gondii on lymph nodes in sheep, or whether the nodes play a part in either the dissemination or containment of the infection. To examine the effect of $T$. gondii on lymph nodes, the efferent popliteal lymphatic ducts were cannulated. After the injection of toxoplasms the lymph was tested for the presence of the parasite, and the nodes were examined for pathological changes. 


\section{MATERIALS AND METHODS}

Sheep were either females or castrated males, aged 1-2 years, of the Scottish Blackface or Cheviot breed. Popliteal efferent-lymphatic ducts were cannulated according to published procedures (Hall and Morris, 1962) and the sheep were kept in metabolism crates. Lymph was collected by draining continuously into polyethylene bottles containing a small amount of powdered heparin and antibiotics. Lymph was allowed to flow for at least $48 \mathrm{~h}$ before infection.

$T$. gondii $\left(M_{1}\right.$ strain), originally isolated from an aborted ovine foetus, was grown in mice and the inoculum prepared as already described (Buxton, Reid and Pow, 1979). Six sheep, four without detectable toxoplasma antibody and two with naturally acquired antibody, each received subcutaneously, over the lateral aspect of the metatarsal bone, $0.5 \mathrm{ml}$ of inoculum containing an estimated 100 toxoplasma cysts. Another two sheep without detectable antibody received control inoculum prepared from uninfected mouse brain.

Detection of T. gondii in lymph by mouse inoculation. Throughout the experiment lymph was collected from each infected sheep, except one immune animal, during the same period each morning, and $0.2 \mathrm{ml}$ was injected intraperitoneally into each of two mice. Eight weeks later, sera were collected from the mice and tested for the presence of toxoplasma antibody by radio-immunoassay (Finlayson, 1980); mice that gave a positive reaction were taken to have been inoculated with toxoplasma-infected lymph.

Detection of $T$. gondii in lymph by immunological staining. The number of cells present in lymph in each morning sample was counted with a Coulter Counter ZBI (Coulter Electronic Ltd, Luton, Beds) and the total adjusted to $2 \times 10^{6} / \mathrm{ml}$ by the addition of Hanks's balanced salt solution containing foetal calf serum $1 \cdot 0 \%$. Portions $(200 \mu \mathrm{l})$ were then spun on to glass slides with a Cytospin (Shandon Southern Products Ltd, Runcorn, Cheshire). Slides were air-dried and fixed in methanol for $10 \mathrm{~min}$, treated with borohydride $0.2 \%$ in phosphate buffer $p \mathrm{H} \mathrm{7.4}$, and rinsed in buffer. They were then treated with mouse anti-toxoplasma IgG conjugated with alkaline phosphatase (Avrameas, 1969); histochemical colouration of the enzyme was produced by the naphthol-AS method (Avrameas, 1969).

Each sheep was killed when, 9-15 days after infection, lymph ceased to flow in the cannula. At necropsy the cannulated popliteal lymph node, the internal-iliac lymph node from the same side, and the spleen were removed. Small blocks of each of these tissues were then fixed in $95 \%$ ethanol at $4^{\circ} \mathrm{C}$ overnight, and processed to the paraffin-wax stage by the St Marie method (Pearse, 1980); the remaining tissue was fixed in Baker's calcium formol and embedded in paraffin wax. Sections were cut and stained with haematoxylin and eosin, methyl green pyronin, Gordon and Sweet's stain for reticulin, and Martius scarlet-blue method for fibrin (Drury and Wallington, 1967).

Detection of antibody to $T$. gondii in lymph. The lymph was tested by means of radio-immunoassay as described by Finlayson (1980).

Demonstration of T. gondii in tissue sections. Sections $6 \mu \mathrm{m}$ thick were cut from St Marie-processed blocks. After being dewaxed, endogenous peroxidase activity was blocked (Heyderman and Neville, 1977), and sections were treated with rabbit anti-toxoplasma serum followed by sheep anti-rabbit IgG, or by normal rabbit IgG conjugated with peroxidase. Histochemical colouration of the enzyme was produced by the application of diamino-benzidine (Avrameas, 1969).

Demonstration of immunoglobulin in tissue sections. Sections of St Marie-processed, Bouin-fixed tissues were treated with rabbit $\mathrm{F}\left(\mathrm{ab}^{\prime}\right)_{2}$ anti-sheep Fab (Miller and Adams, 1977) followed by sheep $F\left(a^{\prime}\right)_{2}$ anti-rabbit Fab-peroxidase conjugate (Miller, Huntley and Dawson, 1981). Specificity controls included those previously described (Miller and Adams, 1977), and peroxidase activity was revealed with diamino-benzidine. Tissues were counterstained with haematoxylin.

\section{RESULTS}

Detection of $T$. gondii in lymph by mouse inoculation Live toxoplasms were detected in the lymph of one non-immune sheep 
from the 2nd day of infection, and in the other three non-immune animals by the 5th day (fig. 1). The lymph remained capable of infecting mice until each sheep was killed. Lymph from immune sheep no. 5, which was injected into two mice per day for 16 days, infected only one mouse (see fig. 1, day 7).

\section{Detection of $T$. gondii in lymph by immunological staining}

Toxoplasma tachyzoites were recognised in the lymph of only two non-immune infected sheep. Small groups of extracellular tachyzoites were present in lymph smears on days 7 and 9 from one animal, and day 8 from the other. Tachyzoites were not recognised in smears from the other four infected animals or the two controls.

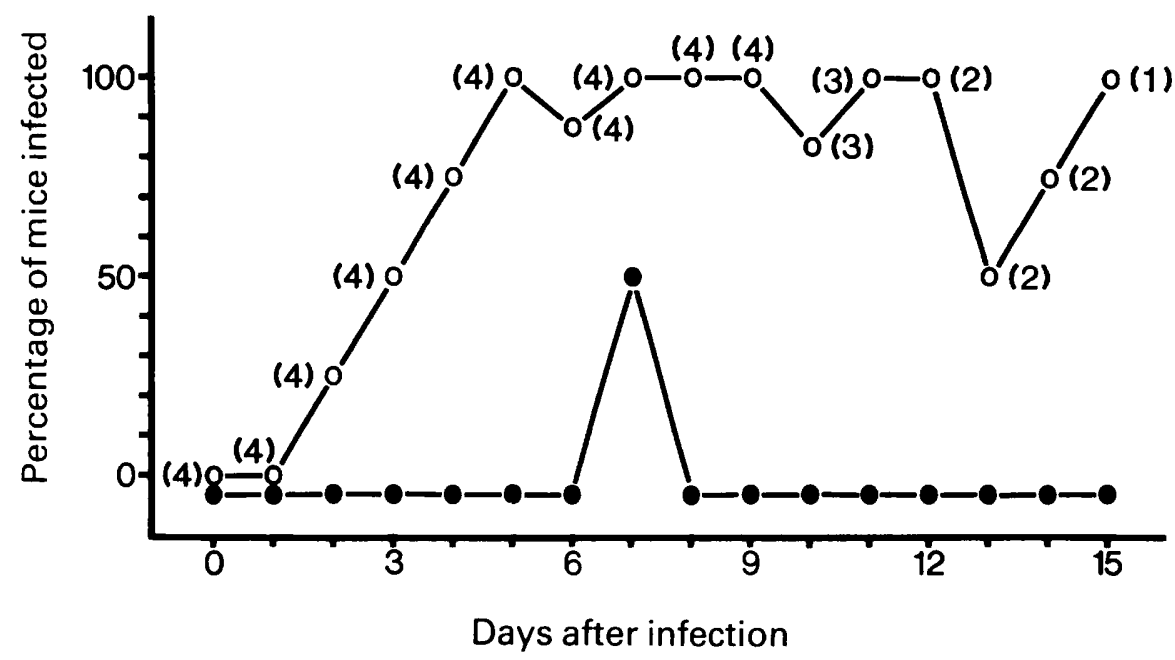

FIG. 1.-Detection of $T$. gondii in lymph by mouse inoculation. $\mathrm{O}-\mathrm{O}=$ Non-immune sheep; the numbers in parenthesis indicate number of sheep from which the lymph was derived. $--=$ Immune sheep no. 5 (see table). Two mice were inoculated with each sample.

\section{Toxoplasma antibody in lymph}

The two immune sheep had a mean pre-inoculation antitoxoplasma activity of 40 counts/s (cps); the activity rose to a mean peak of 95 cps by day 8 , after which it declined. Antibody was not detected in the four non-immune sheep until after day 6 , when the titre rose sharply to reach $66 \mathrm{cps}$ by day 15 (fig. 2).

Detection of T. gondii in lymph-node sections by immunological staining

Toxoplasms were not readily seen in tissue sections of infected popliteal lymph nodes treated with specific toxoplasma antiserum. When present, they were usually in the cytoplasm of moderately sized mononuclear cells in the 


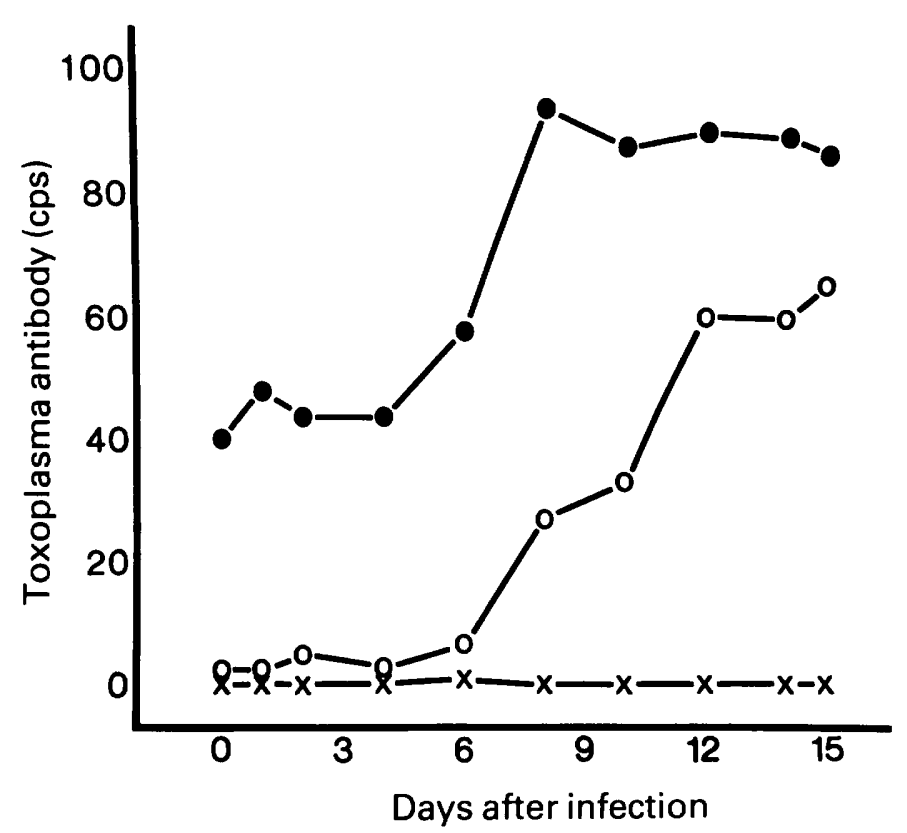

FIG. 2.-Mean antibody activity to $T$. gondii in lymph from non-immune $(\circ-0)$, immune $(\bullet-\bullet)$ and control $(x-x)$ sheep in counts per second.

medullary cords. Only rarely were they seen to be extracellular. Organisms were not detected in uninfected control tissues.

Intracellular tachyzoites were seen in the internal iliac lymph nodes taken from two of the infected sheep.

\section{Pathology of the lymph nodes}

The infected popliteal lymph nodes from non-immune sheep were much enlarged and measured $2.5-3.0 \mathrm{~cm}$ long by $2.0 \mathrm{~cm}$ wide. Petechial haemorrhages were visible in the capsule, medulla, and cortex, and fluid oozed from the cut surface (table). In contrast, the contralateral popliteal lymph nodes were normal in size $(1.0-1.5 \mathrm{~cm}$ long by $0.75-1.0 \mathrm{~cm}$ wide) and did not display haemorrhages. Haemorrages were also absent from infected popliteal lymph nodes taken from the two immune sheep. These nodes were intermediate in size.

Histopathological examination of infected nodes from non-immune sheep revealed that haemorrhages sometimes occurred throughout the node. In the medulla, blood vessels were surrounded by increased amounts of reticulin, and the medullary cords were enlarged and contained many blast cells with large round "open" nuclei and eosinophilic cytoplasm. Medullary sinuses were dilated and packed with lymphocytes and macrophages. Phagocytosed debris was often present in the latter, and toxoplasma tachyzoites were also occasionally found. Numerous blast cells, which gave a positive staining reaction for immunoglobulin (figs. 3 and 4), were found in the paracortex 


\section{$T$. GONDII IN OVINE LYMPH NODES}

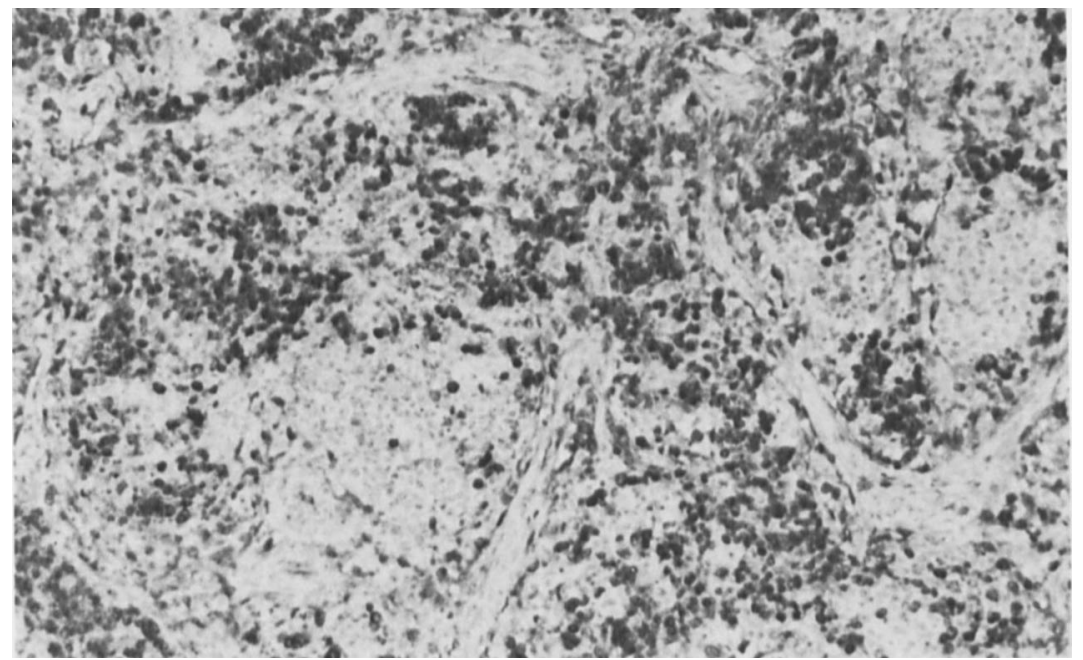

FIG. 3.-Immunoglobulin-containing cells in the cortex of a toxoplasma-infected popliteal node. Bouin-fixed tissue stained with rabbit $F(a b)_{2}$ anti-sheep Fab followed by peroxidase-labelled sheep $\mathrm{F}(\mathrm{ab})_{2}$ anti-rabbit Fab. $\times 32$.

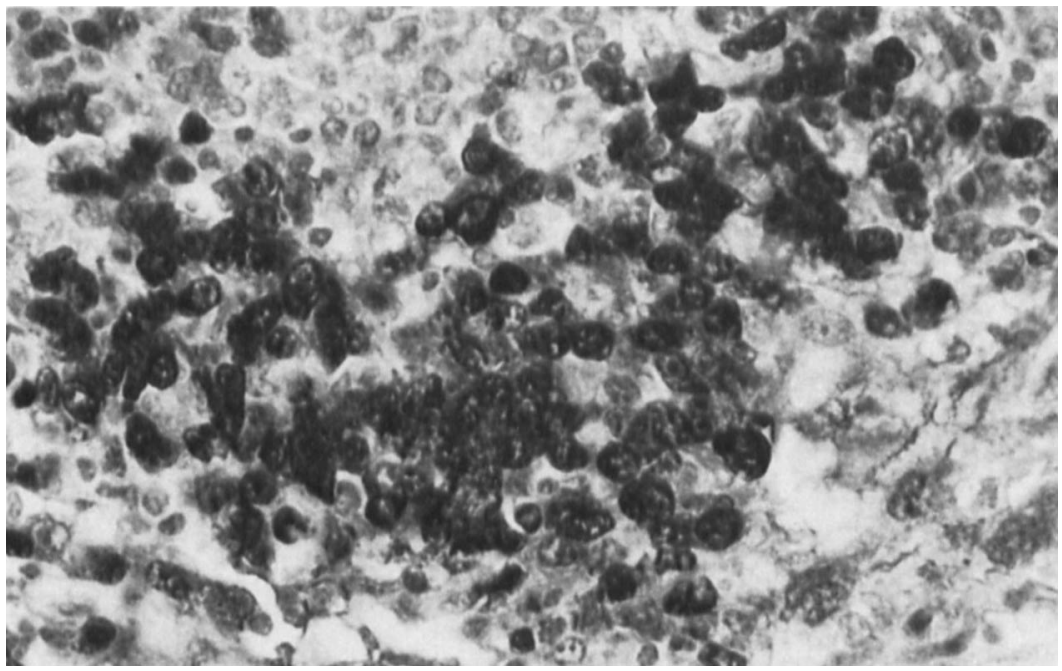

FIG. 4.-Higher-power photograph from the same tissue as that in fig. 3, demonstrating the presence of immuglobulin in plasmablasts and plasma cells 14 days after infection with $T$. gondii. $\quad \times 480$. 
TABLE

Immune status and treatment of sheep, and pathological changes in popliteal lymph node

\begin{tabular}{|c|c|c|c|c|c|c|c|}
\hline \multirow[b]{2}{*}{$\begin{array}{l}\text { Sheep } \\
\text { no. }\end{array}$} & \multirow[b]{2}{*}{$\underset{\text { status }}{\text { Immune }}$} & \multirow[b]{2}{*}{ Treatment } & \multirow{2}{*}{$\begin{array}{l}\text { Period (days) } \\
\text { between } \\
\text { inoculation } \\
\text { and slaughter }\end{array}$} & \multicolumn{4}{|c|}{$\begin{array}{l}\text { Pathological changes in popliteal } \\
\text { lymph node }\end{array}$} \\
\hline & & & & Haemorrhages & $\begin{array}{l}\text { Extravascular } \\
\text { fibrin }\end{array}$ & $\begin{array}{c}\text { Normal } \\
\text { structure } \\
\text { lost }\end{array}$ & $\begin{array}{c}\text { Focal } \\
\text { necrosis }\end{array}$ \\
\hline 1 & NI & $\mathrm{T}$ & 15 & + & + & + & + \\
\hline 2 & $\mathrm{NI}$ & $\mathrm{T}$ & 14 & ++ & - & + & - \\
\hline 3 & NI & $T$ & 11 & ++ & - & + & - \\
\hline 4 & NI & $\mathrm{T}$ & 9 & ++ & - & + & + \\
\hline 5 & I & $T$ & 15 & - & - & - & - \\
\hline 6 & I & $\mathrm{T}$ & 10 & - & + & - & - \\
\hline 7 & NI & $\mathrm{C}$ & 15 & - & - & - & - \\
\hline 8 & NI & $\mathrm{C}$ & 11 & - & - & - & - \\
\hline
\end{tabular}

$\mathrm{NI}=$ non-immune; $\mathrm{I}=$ immune; $\mathrm{T}=$ toxoplasma inoculum; $\mathrm{C}=$ control inoculum; $-=$ no change present; $+=$ change present; $++=$ severe change present.

together with an amorphous eosinophilic ground substance which only sometimes gave a positive reaction for fibrin with MSB stain.

The cortex in uninfected nodes was thin and made up of a single layer of unstimulated primary lymphoid nodules lying adjacent to the capsule. The underlying architecture consisted of circular condensations of reticulin fibres around follicles which were themselves virtually free from reticulin (fig. 5). The cortex in infected popliteal lymph nodes taken from non-immune sheep was thickened and had two to three layers of lymphoid nodules, some with large pale clearly defined reactive centres; others, which had apparently lost their outer rim of lymphocytes, merged with the surrounding interfollicular sinus tissue, and were shown by reticulin staining to be less organised. The follicles were not readily identified because they contained much more reticulin than normal and were, at best, surrounded by a loose indistinct band of reticulin (fig. 6). More usually they merged with the interfollicular tissue, which displayed a paucity of reticulin.

Foci of necrosis were scattered through the cortex of two of the infected popliteal lymph nodes from non-immune sheep (fig. 7). These foci were devoid of reticulin and did not contain fibrin, but intracellular and extracellular toxoplasma tachyzoites were present on the edge of the lesion. The capsule of each infected node was thickened and oedematous and contained a mixed population of inflammatory cells.

Changes in the infected popliteal lymph nodes taken from the two immune sheep showed similar, although less severe, changes. The nodes were enlarged and the cortex was correspondingly thickened; follicles were plentiful and had large, pale reactive centres which contained many mitotic figures. Loss of follicular architecture was not apparent although reticulin fibres were less dense around follicles and in interfollicular tissue. The paracortex was packed with plasma cells and plasmablasts.

Histological changes in the internal-iliac lymph nodes were similar to, but 
less severe than, the changes in the infected popliteal lymph nodes that they drained.

Examination of sections of spleen from infected sheep showed a slight increase in the size of follicles by comparison with uninfected control animals.

\section{Discussion}

In the present study, toxoplasms were not detected in lymph from the experimentally infected non-immune sheep until 2-5 days after inoculation; it seems likely that during the latent period the parasite excysted and proliferated sufficiently to escape into efferent lymph and spread systemically. On the other hand, lymph from the immune sheep was infective on only one occasion, indicating that primed lymph nodes may be better equipped to resist the growth and spread of toxoplasms. It is tempting to suggest that lymphatics are the primary route of spread for toxoplasms. The organism has, however, been detected in blood soon after experimental infection (Jacobs and Hartley 1964; Reid et al., 1981).

The immune response to $T$. gondii is complex. Humoral antibody by itself is not considered to be of primary importance (Lindberg and Frenkel, 1977) because cell-mediated mechanisms have been shown to play the principal role in vitro (Remington, Krahenbuhl and Mendenhall, 1972; Borges and Johnson, 1975; Jones, Len and Hirsch, 1975), and in vivo (Frenkel, 1967; Hoff and Frenkel, 1974). Furthermore, the thymus plays an essential part in the development of immunity to T. gondii (Hof et al., 1976; Buxton, 1980). Inhibition of toxoplasma multiplication has also been brought about by soluble products of thymus-derived $(\mathrm{T})$ lymphocytes that have been sensitised to $T$. gondii and placed in contact with toxoplasma antigen (Borges and Johnson, 1975; Shirahata et al., 1977; Chinchilla and Frenkel, 1978).

In our experiments, antibody to $T$. gondii was not found in lymph until after day 6; despite a subsequent continuing rise in antibody, toxoplasms were detected in lymph until the sheep were killed. The existence in lymph of live toxoplasms and toxoplasma antibody might be considered as another argument against protection by humoral antibody. However, the infectivity of the lymph was not titrated, and it is therefore not known whether the numbers of organisms in lymph changed during infection.

Lymphadenopathy - the commonest clinical manifestation of human toxoplasmosis (Beverley, 1974)-was first recognised in man by Siim (1951). Characteristically, reactive changes are found, with follicular hyperplasia and active germinal centres in which there are large, pale, actively phagocytic macrophages. Increased numbers of plasma cells are present in lymph node medullae (Beverley, 1974). Similar lymph-node changes have been induced experimentally in rabbits (Henry et al., 1973) and mice (Henry and Beverley, 1976). Our studies indicate that $T$. gondii can cause a lymphadenopathy in sheep similar to that seen in man, rabbits and mice.

We are grateful to $\mathrm{Mr} \mathrm{B}$. Easter and $\mathrm{Mr} \mathrm{A}$. Inglis for assistance with photographs. 


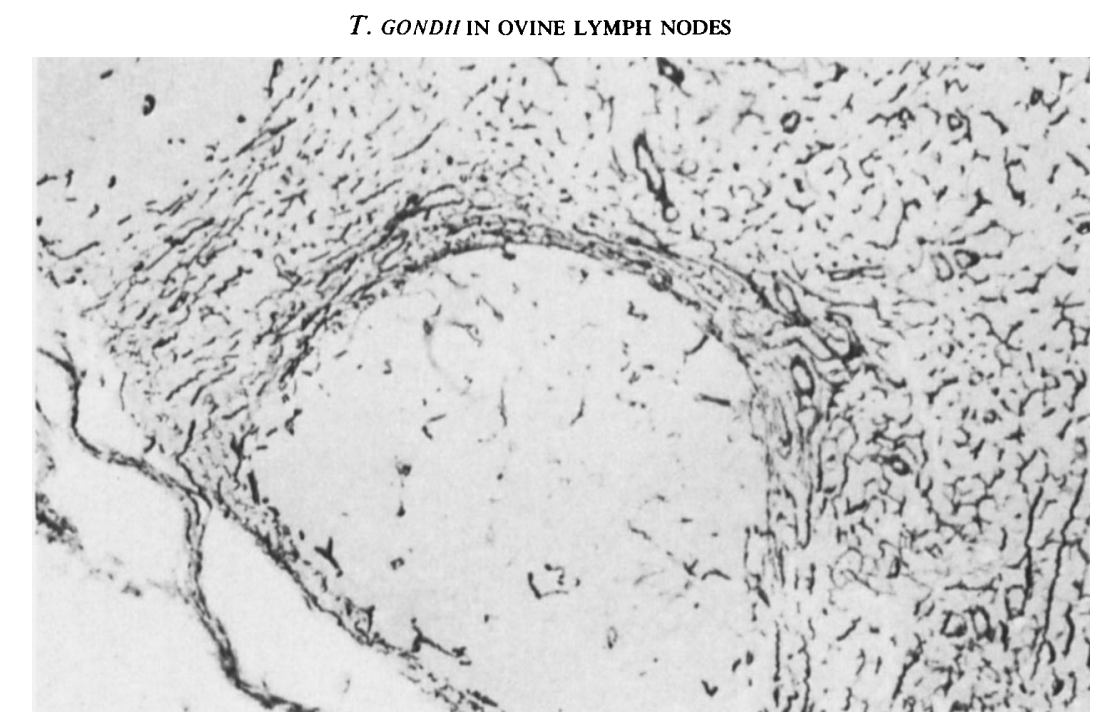

FIG. 5.-Normal distribution of reticulin in cortex of uninfected popliteal lymph node. Note the condensation of fibres surrounding a follicle which is itself almost empty of reticulin. Gordon and Sweet. $\times 120$.

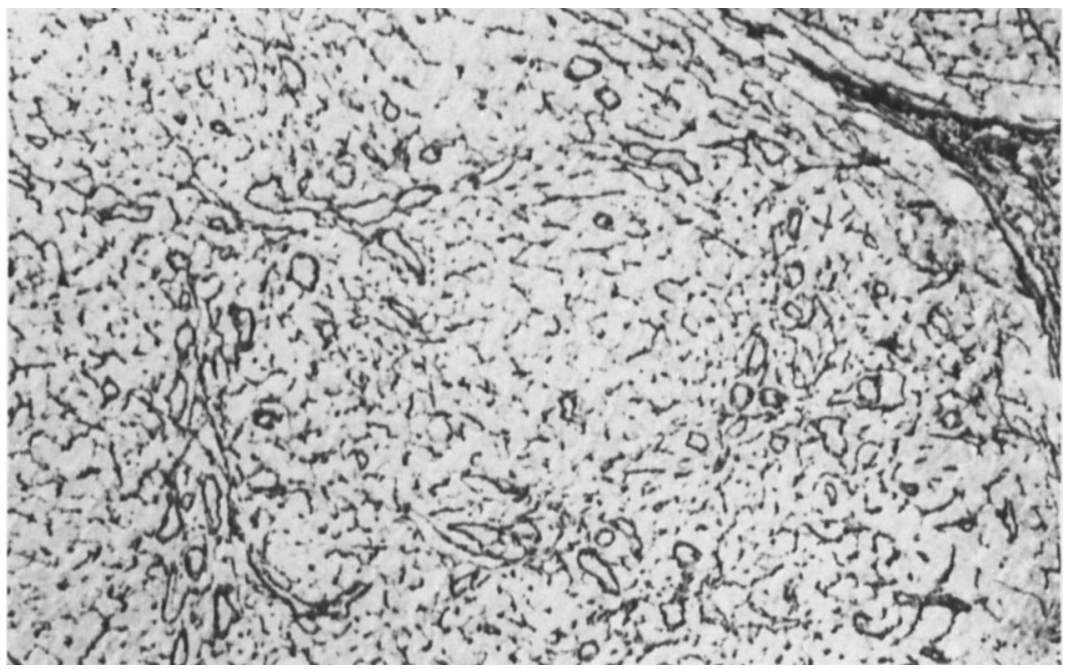

FIG. 6.-Distribution of reticulin in cortex of popliteal lymph node from non-immune sheep 9 days after experimental infection with $T$. gondii. The reticulin-free follicular region is not evident. Gordon and Sweet. $\times 120$. 
T. GONDH IN OVINE LYMPH NODES

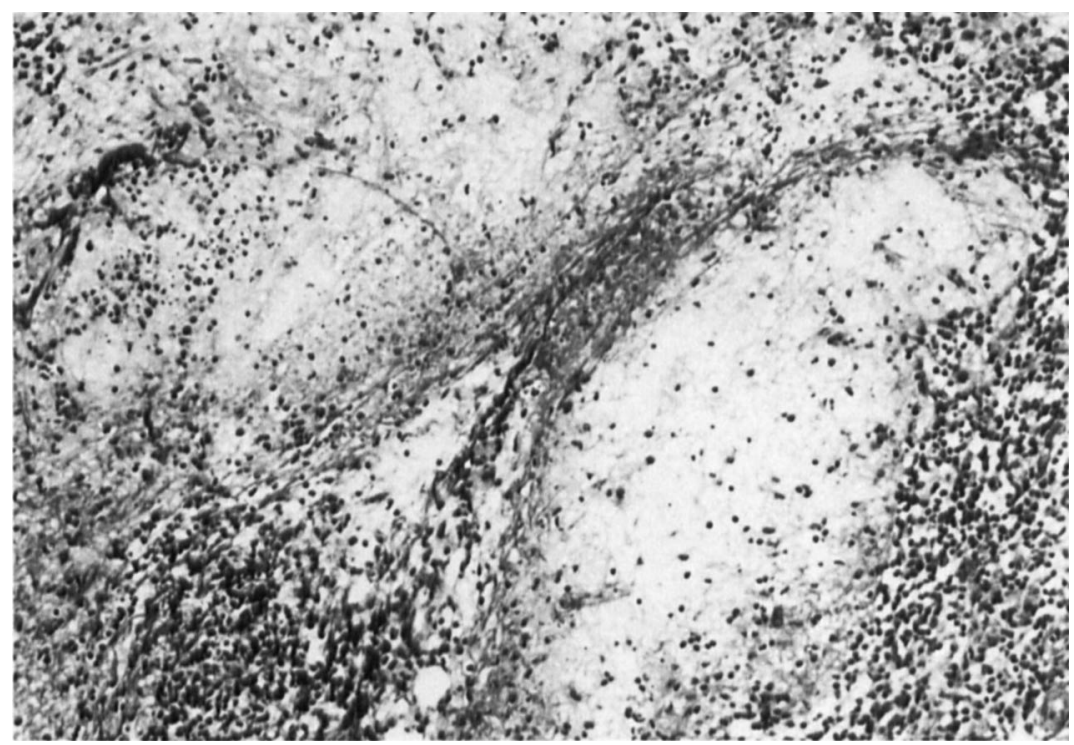

FIG. 7.-Focal necrosis in cortex of popliteal lymph node from non-immune sheep 9 days after infection with T. gondii. Note the pale acellular appearance. Haematoxylin and eosin. $\times 120$. 


\section{REFERENCES}

Avrameas, S. 1969. Coupling of enzymes to proteins with glutaraldehyde. Use of the conjugates for the detection of antigens and antibodies. Immunochemistry, 6, 43.

BeVÉRLEY, J. K. A. 1974. Some aspects of toxoplasmosis, a world wide zoonosis. Parasitic zoonoses; clinical and experimental studies, edited by E. J. L. Soulsby, Academic Press, New York and London, p. 1.

BEVERLEY, J. K. A. AND WATSON, W. A. 1961. Ovine abortion and toxoplasmosis in Yorkshire. Vet. Rec., 73, 6.

BeVerley, J. K. A. AND Watson, W. A. 1971. Prevention of experimental and of naturally occurring ovine abortion due to toxoplasmosis. Vet. Rec., 88, 39.

BORGES, J. S. AND JOHNSON, W. D. 1975. Inhibition of multiplication of Toxoplasma gondii by human monocytes exposed to T-lymphocyte products. J. exp. Med., 141, 483.

Buxton, D. 1980. Experimental infection of athymic mice with Toxoplasma gondii. J. med. Microbiol., 13, 307.

Buxton, D., ReID, H. W. AND Pow, 1. 1979. Immunosuppression in toxoplasmosis: studies in mice with a clostridial vaccine and louping-ill virus vaccine. J. comp. Path., 89, 375.

Chinchilla, M. ANd Frenkel, J. K. 1978. Mediation of immunity to intracellular infection (Toxoplasma and Besnoitia) within somatic cells. Infect. Immun., 19, 999.

DruRy, R. A. B. AND Wallington, E. A. 1967. Carleton's histological technique, 4th ed., Oxford University Press, Oxford.

Finlayson, J. 1980. A microtitre radio-immunoassay for Toxoplasma gondii antibody. $J$. comp. Path., 90, 491.

Frenkel, J. K. 1967. Adoptive immunity to intracellular infection. J. Immun., 98, 1309.

FrenKEL, J. K. 1973. Toxoplasmosis: parasite life cycle, pathology and immunology. The Coccidia, Eimeria, Isospora, Toxoplasma and related genera, edited by D. M. Hammond and P. L. Long, University Park Press, Baltimore, p. 243.

HaLl, J. G. AND MORRIS, B. 1962. The output of cells in lymph from the popliteal node of sheep. Q. J. exp. Physiol., 47, 360.

Hartley, W. J. and Marshall, S. C. 1957. Toxoplasmosis as a cause of ovine perinatal mortality. N.Z. vet. J., 5, 119.

HaRTLEY, W. J. AND MoyLe, G. 1968. Observations on an outbreak of ovine congenital toxoplasmosis. Aust. vet. J., 44, 105.

HeNRY, L. AND Beverley, J. K. A. 1976. The response of the mouse R-E system to infection with Toxoplasma gondii. Virchows Arch. B. cell Path., 20, 55.

Henry, L., Beverley, J. K. A., Shortland, J. R. ANd Coup, A. J. 1973. Experimental toxoplasmic lymphadenopathy in rabbits. Br. J. exp. Path., 54, 312.

Heyderman, E. AND Neville, A. M. 1977. A shorter immunoperoxidase technique for the demonstration of carcinoembryonic antigen and other cell products. J. clin. Path., 30, 138.

Hof, H., Emmerling, P., Höhne, K. and Seeliger, H. P. R. 1976. Infection of congenitally athymic (nude) mice with Toxoplasma gondii. Annls Microbiol., Inst. Pasteur, 127B, 503.

HofF, R. L. AND Frenkel, J. K. 1974. Cell-mediated immunity against Besnoitia and Toxoplasma in specifically and cross-immunized hamsters and in cultures. J. exp. Med., 139, 560.

JACOBS, L. AND HARTLEY, W. J. 1964. Ovine toxoplasmosis: studies on parasitaemia, tissue infection, and congenital transmission in ewes infected by various routes. Br. vet. J., 120, 347.

Jones, T. C., Len, L. AND HirsCh, J. G. 1975. Assessment in vitro of immunity against Toxoplasma gondii. J. exp. Med., 141, 466.

LindBerg, R. E. AND Frenkel, J. K. 1977. Toxoplasmosis in nude mice. J. Parasit., 63, 219.

Miller, H. R. P. AND Adams, E. P. 1977. Reassortment of lymphocytes in lymph from normal and allografted sheep. Am. J. Path., 87, 59.

Miller, H. R. P., HunTLEY, J. F. AND Dawson, A. MCL. 1981. Mucus secretion in the gut; its relationship to the immune response in Nippostrongylus-infected rats. In Current topics in 
veterinary medicine and animal science, edited by F. J. Bourne, Martinus and Nijhoff, London and The Hague.

Pearse, A. G. E. 1980. Histochemistry, theoretical and applied, vol. 1, 4th ed., Churchill, London.

Reid, H. W., Buxton, D., Gardiner, A. C., Pow, I., Finlayson, J. and Maclean, M. J. 1981. Immunosuppression in toxoplasmosis: studies in lambs and sheep infected with louping-ill virus. J. comp. Path. (in press).

Remington, J. S., KRahenduhl, J. L. and Mendenhall, J. W. 1972. A role for activated macrophages in resistance to infection with Toxoplasma. Infect. Immun., 6, 829.

Shirahata, T., Shimizu, K., Noda, S. AND Suzuki, N. 1977. Studies on production of biologically active substance which inhibits the intracellular multiplication of Toxoplasma within mouse macrophages. Z. ParasitKde, 53, 31 .

Silm, J. C. 1951. Acquired toxoplasmosis. Report of seven cases with strongly positive serologic reactions. J. Am. med. Ass., 147, 1641. 